\title{
Olfactory Foraging by Antarctic Procellariiform Seabirds: Life at High Reynolds Numbers
}

\author{
GABRIELLE A. NEVITT \\ Section of Neurobiology, Physiology and Behavior, University of California, Davis, California 95616
}

\begin{abstract}
Antarctic procellariiform seabirds forage over vast stretches of open ocean in search of patchily distributed prey resources. These seabirds are unique in that most species have anatomically well-developed olfactory systems and are thought to have an excellent sense of smell. Results from controlled experiments performed at sea near South Georgia Island in the South Atlantic indicate that different species of procellariiforms are sensitive to a variety of scented compounds associated with their primary prey. These include krill-related odors (pyrazines and trimethylamine) as well as odors more closely associated with phytoplankton (dimethyl sulfide, DMS). Data collected in the context of global climatic regulation suggest that at least one of these odors (DMS) tends to be associated with predictable bathymetry, including upwelling zones and seamounts. Such odor features are not ephemeral but can be present for days or weeks. I suggest that procellariiforms foraging over vast distances may be able to recognize these features reflected in the olfactory landscape over the ocean. On the large scale, such features may aid seabirds in navigation or in locating profitable foraging grounds. Once in a profitable foraging area, procellariiforms may use olfactory cues on a small scale to assist them in locating prey patches.
\end{abstract}

\section{Introduction}

How olfactory-guided search strategies operate over distances of hundreds or thousands of kilometers has not been rigorously studied in most organisms that use them, yet these behaviors stand as some of the most remarkable navigational feats of nature. Pacific salmon (Oncorhynchus sp.), for example, migrate thousands of kilometers to specific streams. This behavior is thought to be guided largely by smells learned earlier in life (for review, see Hasler and Scholz, 1983; Nevitt and Dittman, 1998). Green sea turtles

Received 1 July 1999; accepted 24 November 1999.

E-mail: ganevitt@ucdavis.edu
(Chelonia mydas) nesting on Ascension Island in the middle of the Atlantic Ocean are guided there from feeding grounds off the coast of South America, presumably by a redundant set of mechanisms that possibly includes an ability to smell their island birth place (for review, see Lohmann, 1992).

To explain such behaviors, it is commonly assumed that animals are able to recognize and follow odors emanating from a distant source. This logic predicts that a recognizable odor signature emanates from a site, forming a gradient that can be detected thousands of kilometers away. By some adaptive behavioral mechanism such as turning or swimming upstream in response to the odor cue, the animal focuses its directional movement to locate the source of the odor plume. This hypothesis thus suggests that a salmon entering a river system should be able to detect the scent of its homestream waters from many hundreds of kilometers downstream. Similarly, a sea turtle foraging off the coast of Brazil should be able to detect and respond to odors emanating from a remote island thousands of kilometers away. But the physical parameters that dictate these behaviors do not support such scenarios. Odors are transported in a turbulent environment, suggesting that gradients are not easy to follow (see discussion in Dusenbery, 1992). Moreover concentrations of site-specific odors would be small and probably undetectable from the distances being considered

My laboratory has been studying this problem in a novel context-olfactory foraging at sea by Antarctic procellariiform seabirds (Order Procellariiforms). These tube-nosed seabirds include the petrels, albatrosses, and shearwaters. Procellariiform seabirds forage over hundreds and even thousands of kilometers in search of patchily distributed food resources, most notably krill, squid, and fish (reviewed in Prince and Morgan, 1987, and Warham, 1990). Members of this order have among the largest olfactory bulbs of any bird, suggesting that olfaction plays a fundamental role in foraging behavior (Bang, 1965, 1966). Experimental trials performed at sea and from land have shown that many 


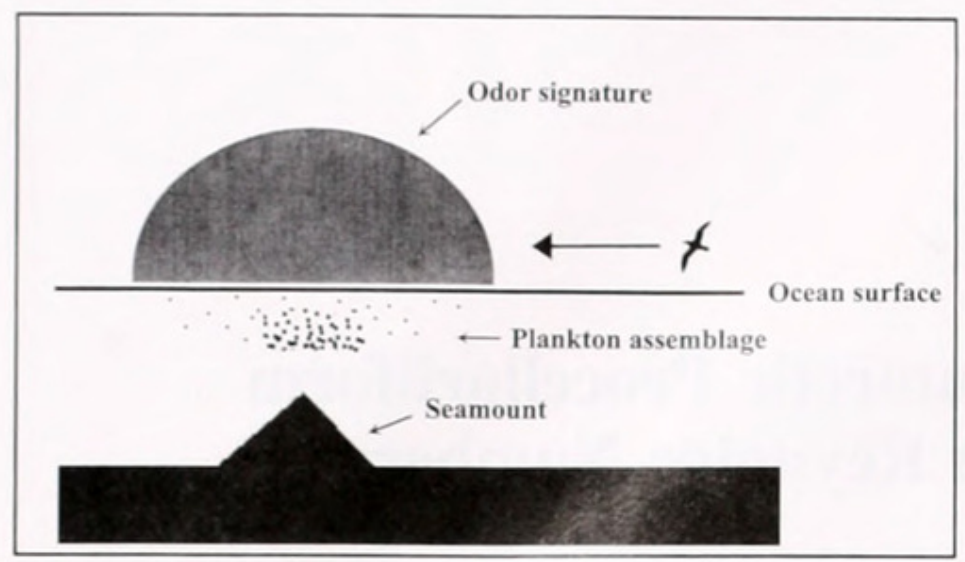

Figure 1. A theoretical olfactory landscape in the atmosphere reflects biological activity over a seamount. This is an area of upwelling where primary productivity tends to be high. A seabird may be alerted to a potentially productive foraging area as it encounters a change in the olfactory landscape. Elements are not drawn to scale.

species are attracted to fishy odors (e.g., cod liver oil, tuna oil, or fish homogenate). Such studies suggest that procellariiforms use their sense of smell to locate food patches (Grubb, 1972; Hutchison and Wenzel, 1980; Lequette et al., 1989; Nevitt et al., 1995).

On a broader scale, we are only beginning to investigate how procellariiforms use naturally occurring scented compounds as foraging and navigation cues (Figs. 1 and 2). I suggest that odors serve at least three distinct functions. First, for species that travel long distances to forage, contours in an odor landscape superimposed upon the ocean's surface may serve as olfactory guideposts that mark the path the seabird follows (see also Waldvogel, 1987). For example, a seabird might gain directional information by traveling along a shelf break or another bathymetric feature that is marked by a consistent olfactory signature in the atmosphere (Fig. 2A). Second, olfactory landscapes may demarcate large-scale areas where prey is likely to be found (Figs. 1 and 2B). Such areas include upwelling zones or seamounts where primary productivity is likely to be high (Fig. 1). Finally, odor cues emitted from prey or directly associated with prey may assist seabirds using area-restricted search to locate prey patches (Fig. 2C). This area-restricted search has been described elsewhere (Nevitt and Veit, 1999) and is likely to involve both visual cues provided by foraging conspecifics and olfactory cues from prey. Although these findings do not support a gradient or bicoordinate odor-map mechanism as proposed for homing pigeons (Papi et al., 1972; Wallraff, 1981), they do fit well with other models that more realistically describe atmospheric transport of directional olfactory cues for birds (see review by Waldvogel, 1987). Our work expands upon this earlier effort by identifying dimethyl sulfide (DMS) as a specific component of the olfactory landscape that procellariiform seabirds can detect.

\section{Foraging at Different Spatial Scales}

Procellariiform seabirds breed on oceanic islands and spend most of their lives at sea. During the breeding season, members of this order are tied to the nesting colony and are thus restricted to central place foraging strategies (Stephens and Krebs, 1986). They must regularly return to the colony either to relieve their mates during the incubation stage or to provision their offspring. Their prey resources are patchy and ephemeral, and foraging grounds may be considerable distances from breeding colonies. These seabirds employ highly efficient flight styles (Pennycuick, 1982, 1987), and thus may be constrained less by their own energetic limitations than by time and energetic limitations imposed on them during the breeding season when mates and chicks depend on successful foraging trips.

I speculate that procellariiform seabirds must confront two fundamental problems to forage efficiently. They must first employ large-scale foraging strategies to locate resource-rich areas where the probability of encountering a prey patch is high. Then they must shift to smaller scale foraging behaviors to pinpoint accessible prey patches within these foraging areas. How have different procellariiform species solved these problems?

One approach is to forage along a path where prey might be encountered opportunistically (Fig. 3, top, reviewed by Weimerskirch, 1998). Wandering albatrosses (Diomedea exulans) regularly use this first foraging scenario, searching for and exploiting resources continuously upon leaving the colony (Jouventin and Weimerskirch, 1990; Weimerskirch et al., 1993; 1994). Satellite tracks of individual breeding wandering albatrosses have shown that these seabirds routinely forage along thousands of kilometers during incubation periods and when provisioning chicks on the nest

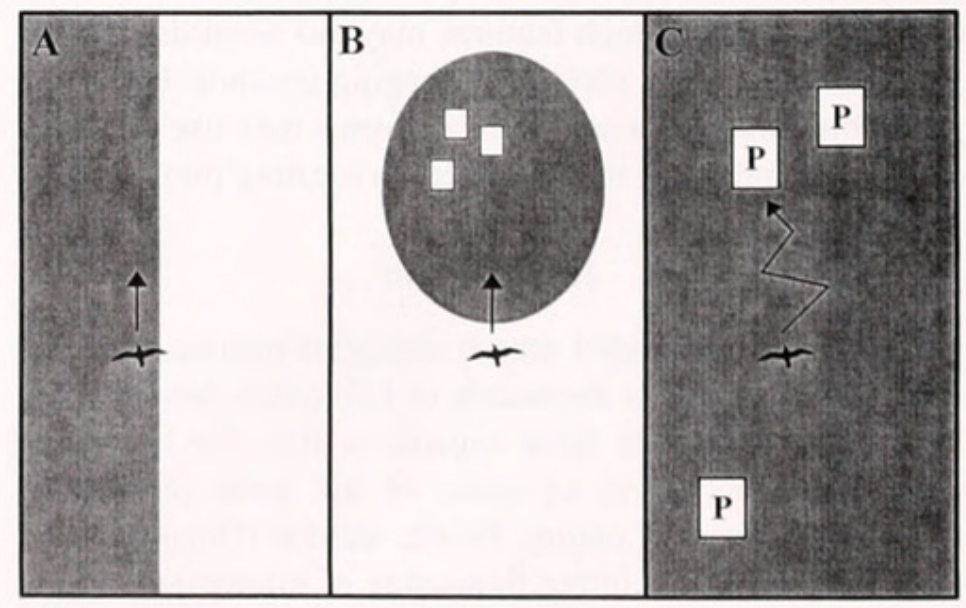

Figure 2. Three ways procellariiform seabirds might use odor features. (A) A large-scale boundary may provide consistent directional information for piloting. (B) A large-scale odor signature may indicate a productive area of the ocean where prey is likely to be found. (C) Once in a productive area, birds may track prey using smell. For each diagram, odor features are indicated in gray. White squares depict prey patches in B and C. Elements of these three models are not drawn to scale. 

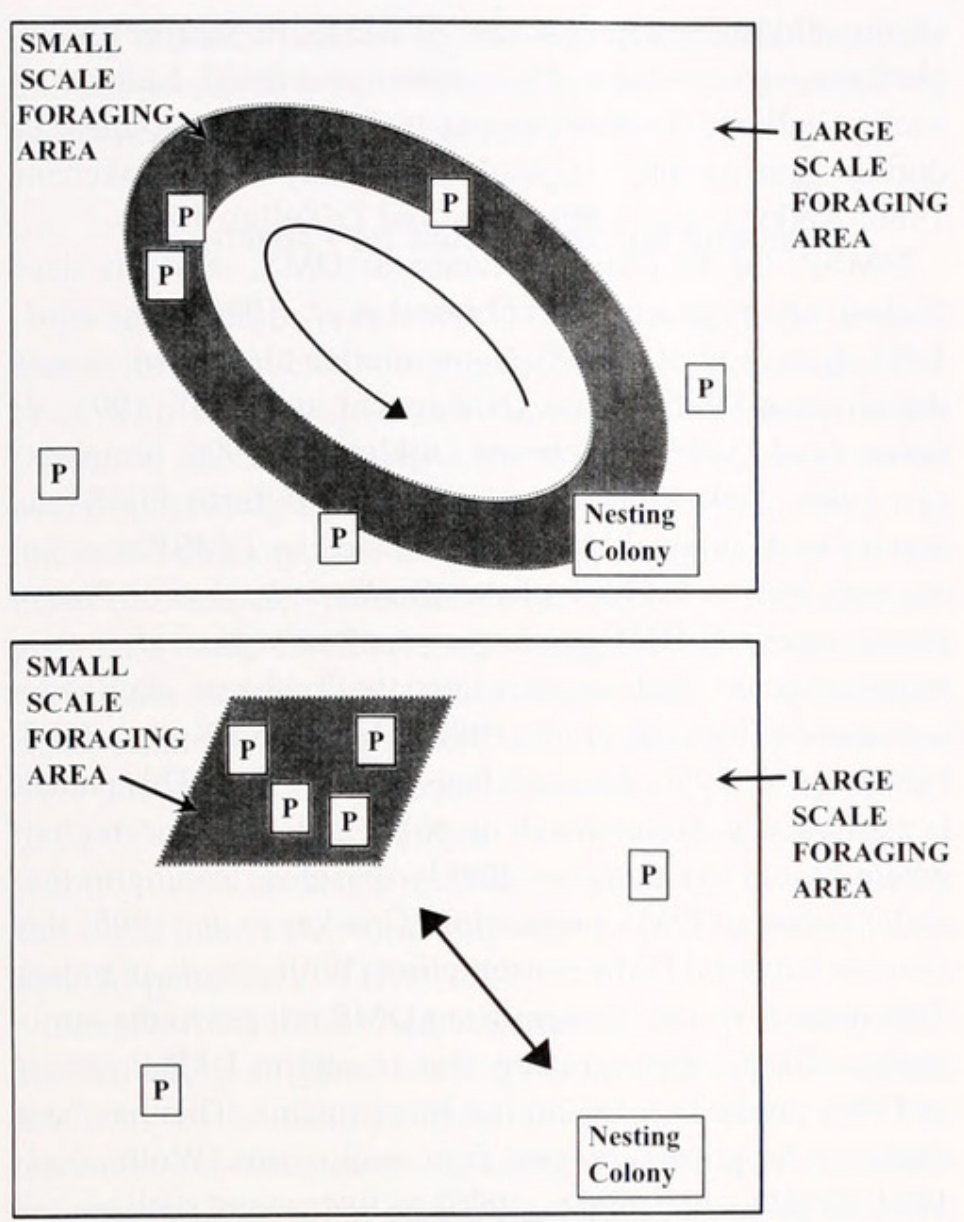

Figure 3. Two strategies used by long-distance foragers. (Top) Opportunistic foraging along a theoretical route (shaded grey) where prey is likely to be encountered. (Bottom) Commuting to distant foraging localities (shaded grey). For both models, white boxes labeled "P" indicate theoretical prey patches. Elements are not drawn to scale.

(Jouventin and Weimerskirch, 1990). Additionally, results from stomach temperature devices deployed in foraging wandering albatrosses indicate that these seabirds feed regularly throughout a foraging trip, swallowing on average one prey item every $100 \mathrm{~km}$ (Weimerskirch and Wilson, 1992). Several studies have shown that this species feeds primarily on deep-water squid (e.g., Onychoteuthidae, Cranchiidae, and Histioteuthidae; Weimerskirch et al., 1986; Rodhouse et al., 1987; Ridoux, 1994) that live well beyond the diving capacities of these seabirds (Croxall and Prince, 1994).

How these birds find this prey resource is still not known. It has been suggested that wandering albatrosses may feed at night when squid migrate to the surface (Croxall and Prince, 1994) or on carrion associated with the foraging activity of sperm whales (Ainley et al., 1984). Another interesting but unexplored possibility is that wandering albatrosses exploit this resource by systematically foraging in areas where this food source is likely to be available, such as along established routes where sperm whales forage. Whether these seabirds also use large-scale olfactory features as guideposts (as shown in Fig. 2A) for foraging has not yet been explored, but presents an interesting avenue for future study. On the small scale, we hypothesize that, as seabirds forage along a course, odor cues emitted by prey enhance encounter rates by, in effect, increasing the prey patch size, thereby increasing foraging efficiency (as in Fig. 2C). Through simulations of dispersion profiles of fishysmelling scented compounds (trimethylamine), Clark and Shah (1992) have shown that odor emissions may extend the detectability of a small $(0.5 \mathrm{~m})$ prey patch by kilometers. The olfactory sensitivities of wandering albatrosses to squid-related odors have not been explored, but albatrosses have been seen to recruit to fishy odors (e.g., herring oil, cod liver oil) in experimental trials (Nevitt, unpubl. data), suggesting that they do pay attention to olfactory cues (see also Hutchison and Wenzel, 1980).

The second strategy that foraging procellariiforms use is to commute directly from the colony to feeding grounds, often hundreds or thousands of kilometers away (Fig. 3, bottom; e.g., Weimerskirch, 1998). To find such locations, procellariiforms may rely on spatial memory, experience, olfactory guideposts, and other navigational cues (e.g., celestial or magnetic). It is unlikely that they are able to perceive prey-related odor cues emanating from such extreme distances, but they could use large-scale olfactory features in the environment as indicators that they have arrived in an area where foraging is likely to succeed (Fig. 2B; Nevitt et al., 1995; Nevitt, 1999a). Olfactory cues may operate on a large scale by alerting seabirds to specific areas of the ocean where food is likely to be available, and thus worth the energetic costs of launching a small-scale search. According to this logic, long-distance foragers would use a change in the odor landscape as a feature in the environment that indicates they have arrived at a specific destination (as in Figs. 1B and 2B). It should be noted that these foraging destinations, particularly upwelling zones or fronts, are not constant but may fluctuate to some degree in space. An olfactory feature that mirrors productivity in a vast expanse of open ocean would provide the foraging seabird with direct and instantaneous feedback that it has reached its foraging destination. Such feedback might trigger a behavioral switch to begin an area-restricted search (as in Fig. 2C). This search would be aimed at locating specific prey patches, and as mentioned above, might involve both olfactory and visual modalities (Nevitt and Veit, 1999).

Evidence for this idea comes largely from two sources: atmospheric data showing associations of biogenic scented compounds with prey resources or areas where prey is likely to aggregate (Fig. 4; see discussion below) and satellite telemetry data collected from foraging seabirds such as black-browed albatross (Thalassarche melanophrys, Cherel and Weimerskirch, 1995; Weimerskirch, 1998), greyheaded albatross (Thalassarche chrysostoma, Prince et al., 1998), light-mantled sooty albatross (Phoebetria palpebrata, Weimerskirch and Robertson, 1994), Southern Buller's albatross (Thalassarche bulleri, Sagar and Weimerskirch, 1996), waved albatross (Phoebetria irrorata, 


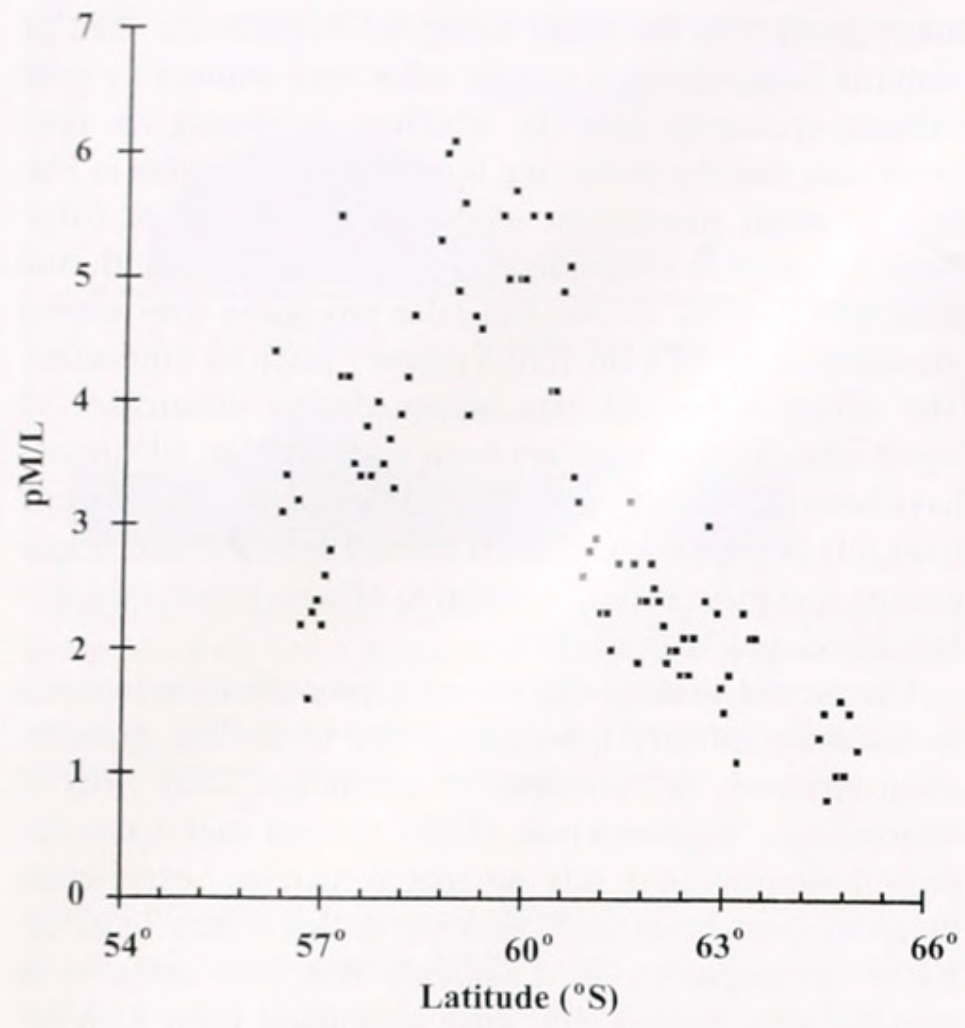

Figure 4. Profile of atmospheric dimethyl sulfide (DMS) measured across the Drake Passage during the RITS cruise, 1993. This profile reflects the polar frontal zone and is an obvious feature in the olfactory landscape. Sampling methods are described elsewhere (Yvon et al., 1996; Bates and Quinn, 1997)

Anderson et al., 1998), and white-chinned petrels (Procellaria aequinoctialis, Catard and Weimerskirch, 1998). Black-browed albatrosses, for example, travel thousands of kilometers to forage at distant feeding grounds. These seabirds begin an area-restricted search only upon arrival (Veit and Prince, 1997, also see discussion in Nevitt and Veit, 1999). Optimal foraging models suggest that animals exploiting distant food sources should move rapidly and directly to feeding areas to minimize time spent in transit, and once there, should remain until they have met their energy needs (Charnov, 1976; Stephens and Krebs, 1986). Thus, it may be more efficient in terms of both time and energy to ignore less significant foraging opportunities en route and travel directly to areas of known productivity. Moreover, identifiable odor molecules that are linked to productive areas of ocean are likely to be important cues for a foraging seabird.

\section{Dimethyl Sulfide as a Signal Molecule}

Sulfur compounds are abundant in polar waters (Berresheim, 1987; Gibson et al., 1990a, b, 1996; Yang et al., 1992, 1994; Crocker et al., 1995; Turner et al., 1995), and recent experimental evidence suggests that many procellariiforms may use at least one of these compounds-dimethyl sulfide (DMS) - as a foraging cue (Nevitt et al., 1995). Marine DMS is a byproduct of the metabolic decomposition of dimethylsulfoniopropionate (DMSP) in marine phytoplankton (most notably Phaeocystis pouchetii). Laboratory studies indicate that this process is dramatically accelerated during grazing by zooplankton (Dacey and Wakeham, 1986; Kellor et al., 1989; Daly and DiTullio, 1996).

DMSP, the biogenic precursor to DMS, is synthesized exclusively by phototrophs (Trossat et al., 1996; Gage et al., 1997; Kocsis et al., 1998). Some marine algae also contain the enzyme DMSP lyase (Nishiguchi and Goff, 1995; de Souza et al., 1996; Stefels and Dijkhuizen, 1996; Steinke et al., 1996, 1998) that cleaves DMSP to form DMS and acrylic acid. In algal blooms dominated by DMSP-containing taxa such as the haptophytes Emiliania huxleyi or Phaeocystis pouchetii, DMS production is often highest after algal biomass peaks and is associated with bloom decline or senescence (Nguyen et al., 1988; Matrai and Keller, 1993; Gibson et al., 1996; Zimmer-Faust et al., 1996). This pattern is particularly pronounced in polar and subpolar regions where bloom dynamics are highly seasonal, leading to dramatic pulses of DMS production (Crocker et al., 1995) that saturate bacterial DMS consumption (Wolfe et al., in press). This process results in significant DMS release to the atmosphere. Zooplankton grazing also results in DMSP release or DMS production by similar mechanisms. This has been observed for grazers ranging from protozoans (Wolfe et al., 1994; Wolfe and Steinke, 1996) to metazoans such as calanoid copepods (Dacey and Wakeham, 1986; Levasseur et al., 1996; Christaki et al., 1996) or krill (Tokunaga et al., 1977; Daly and DiTullio, 1996). Thus, DMS production is often associated with zooplankton feeding (Leck et al., 1989; Cantin et al., 1996) and may even be used as a measure of grazing rate in some instances (Kwint and Kramer, 1996; Wolfe and Steinke, 1996).

Zooplankton retain algal DMSP and transfer it to higher trophic levels; in fact the breakdown of DMSP to DMS and acrylic acid has been shown to cause odor problems in seafood products (G. Wolfe, California State University, Chico, pers. comm.). In an early study, Sieburth (1959, 1960, and 1961) reported high concentrations of acrylic acid in the gastrointestinal systems of penguins, which depressed their microfloral populations. These seabirds fed on krill containing DMSP from the alga Phaeocystis, a dominant taxon in Antarctic waters. Thus, both DMS and acrylic acid are good candidates for chemical signals that operate across temporal and spatial scales, ranging from picoplankton (Bell and Mitchell, 1972; Hauser et al., 1975) to vertebrates.

Because DMS is transferred to the atmosphere, this signal molecule might serve as a guidepost to a seabird trying to locate and exploit zooplankton-rich areas. Mesoscale spatial patterns of DMS production are complex and need to be better quantified, but DMS production has been linked to the presence of krill (Daly and DiTullio, 1996) and to areas where primary productivity is traditionally high (Fig. 4; McTaggart and Burton, 1992). If procellariiform seabirds can detect DMS, then emissions that last for several days 
present distinct features in the odor landscape that may indicate locations where foraging is likely to be productive (Berresheim, 1987; Nevitt et al., 1995).

\section{Seabirds Can Smell Dimethyl Sulfide}

To test seabirds' responses to DMS in the field, experiments from our laboratory have involved presenting seabirds with scented slicks and aerosols. These experiments (Nevitt et al., 1995; Nevitt, 1999b) were conducted at sea near South Georgia Island $\left(54^{\circ} 30^{\prime} \mathrm{S}, 37^{\circ} 00^{\prime} \mathrm{W}\right)$, a region of the world that supports an extensive assemblage of procellariiform seabirds (Croxall et al., 1984). Seabirds were presented with DMS-scented vegetable oil slicks paired with plain vegetable oil slicks as controls. At some locations, seabirds were presented with slicks scented with cod liver oil, an odor complex known to attract procellariiforms (e.g., Hutchison and Wenzel, 1980). We predicted that if seabirds were attracted to DMS and used it as a foraging cue, then their behavioral response to DMS should mirror their response to cod liver oil.

Results from these slick experiments showed that DMSscented slicks attracted some species of procellariiforms as much as twice as frequently as control slicks did. The response was also species-specific. Cryptic species including prions (Pachyptila sp.), white-chinned petrels (Procellaria aequinoctialis), Wilson's storm-petrels (Oceanites oceanicus), and black-bellied storm-petrels (Fregetta tropica) showed a significant interest in DMS-scented slicks as compared with control slicks, whereas more visible species such as Cape petrels (Daption capense) and black-browed, greyheaded, and wandering albatrosses showed no noticeable differences in their responses to the two slicks. Moreover, patterns of recruitment to cod-liver-scented slicks were similar to patterns observed in response to DMS-scented slicks, suggesting that DMS was just as potent as this food-related odor in attracting certain species (see Nevitt, 1999b).

The use of DMS as a foraging cue was tested in a different set of experiments in which we monitored the degree to which individuals zigzagged upwind when presented with scented and unscented aerosols (Nevitt et al., 1995). This behavior had been described previously (Hutchison and Wenzel, 1980), and it presumably directs the seabird to the source of an odor plume-in this case an aerosol delivery system. We predicted that if a seabird were interested in DMS, then it would zigzag more in the presence of a DMS-scented plume than of an unscented aerosol spray, and that this behavior could be measured as a difference in turning rate. Results from experiments supported our previous findings: white-chinned petrels showed a $25 \%$ increase in their turning rate when presented with a DMSscented aerosol. (Note that these seabirds had also displayed a significant attraction to DMS-scented slicks as compared with plain vegetable oil.) Black-browed albatrosses, on the other hand, did not turn any more frequently in response to
DMS-scented aerosols than in response to controls, suggesting that these seabirds do not use this specific odor cue to locate prey patches (as in Fig. 2C; note that behaviors represented in Fig. $2 \mathrm{~A}$ and $\mathrm{B}$ were not addressed in this study).

\section{Procellariiforms May Associate with Natural Emissions of Dimethyl Sulfide}

To begin to explore whether procellariiforms forage in areas where atmospheric DMS is naturally elevated, we have recently analyzed seabird survey data collected as part of the 1993 Radioactively Important Trace Species (RITS) cruise. The cruise track crossed the Drake Passage to Palmer Station on the Antarctic Peninsula, continued southwest to about $67^{\circ} \mathrm{S}, 140^{\circ} \mathrm{W}$, and then headed north to $57^{\circ} \mathrm{N}, 140^{\circ} \mathrm{W}$. Sulfur, carbon, and nitrogen gas phase species were measured to quantify their cycling in the surface ocean and to calculate the exchange of these compounds between the ocean and the atmosphere. Methods for sampling atmospheric DMS are described elsewhere (Yvon et al., 1996; Bates and Quinn, 1997).

Seabird observations were performed from $66^{\circ} \mathrm{S}$ in the Southern Ocean to $30^{\circ} \mathrm{S}$ in the Pacific Ocean over a period of 11 days. To determine background species compositions, all seabirds within a $100-\mathrm{m}$ box, positioned $100 \mathrm{~m}$ off the bow of the ship, were counted using standard methods (Tasker et al., 1984). All observations were conducted in a blind manner, in which the observer was not informed of the local DMS levels. To determine possible correlations between seabird abundance and local concentrations of atmospheric DMS, we examined the percent frequency (per hour) of 24 procellariiform species at low $(0-4.0 \mathrm{p} M / \mathrm{l}$ for atmospheric DMS; $0-1.0 \mathrm{nmol}$ for seawater DMS), medium (4.1-8.0 $\mathrm{pM} / \mathrm{l} ; 1.1-2.0 \mathrm{nmol})$, and high $(8.1-12.5 \mathrm{pM} / \mathrm{l}$; 2.1-3.0 nmol) concentrations of DMS.

We observed a similar distribution of species at low (Fig. 5A) and medium (Fig. 5B) atmospheric DMS concentrations, but only blue petrels (Halobaena caerulea) and prions (Pachyptila sp.) were observed when atmospheric DMS levels were highest (Fig. 5C). In addition, blue petrels and prions were most abundant when atmospheric DMS levels were highest (Fig. 6: (A) Kruskal-Wallis test statistic = $16.110, P<0.0001$, df $=2$ for blue petrels; (B) KruskalWallis test statistic $=12.503, P=0.002, \mathrm{df}=2$ for prions. Tests were performed with Dunn-Sidak corrections to avoid Type-I errors). This finding is consistent with results from earlier work indicating enhanced recruitment of prions to DMS in controlled studies (Nevitt et al., 1995; no data are available for blue petrels). As discussed above, DMS production is an indicator of krill grazing (e.g., Daly and DiTullio, 1996), and most prion diets are composed predominantly of crustaceans, including krill, amphipods, and copepods (e.g., Imber, 1981; Prince and Copestake, 1990; Ridoux, 1994; Liddle, 1994; Reid et al., 1997). Similarly, 


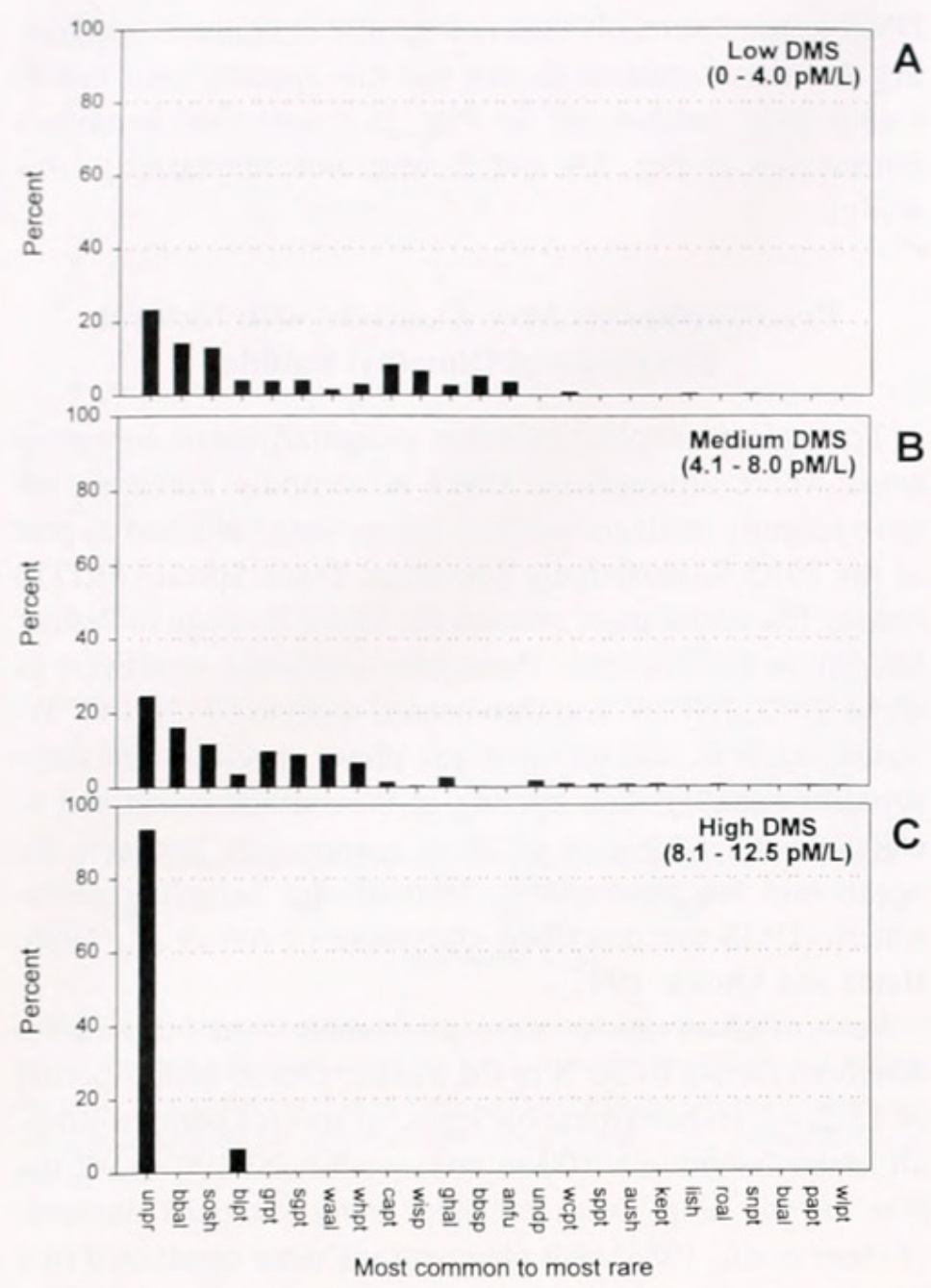

Figure 5. Percent composition of procellariiform seabirds at low (A), medium (B), and high (C) atmospheric concentrations of dimethyl sulfide (DMS). Total number of bird observations was 2860 (low $=620$, medium $=682$, and high $=1558)$. Species abbreviations: unpr $=$ unidentified prion (Pachyptila sp.); bbal = black-browed albatross (Thalassarche melanophris); sosh = sooty shearwater (Puffinus griseus); blpt = blue petrel (Halobaena caerulea $) ;$ grpt $=$ grey petrel $($ Procellaria cinerea $) ; \mathrm{sgpt}=$ southern giant petrel (Macronectes giganteus); waal = wandering albatross (Diomedea exulans); whpt $=$ white-headed petrel (Pterodroma lessonii); capt $=$ Cape petrel $($ Daption capense) ; wisp $=$ Wilson's storm-petrel (Oceanites oceanicus); ghal = grey-headed albatross (Thalassarche chrysostoma $) ;$ bbsp = black-bellied storm-petrel (Fregetta tropica $)$; anfu = Antarctic fulmar (Fulmarus glacialoides); undp = unidentified diving petrel (Pelecanoides sp.); $w \mathrm{cpt}=$ white-chinned petrel $($ Procellaria aequinoctialis); $\mathrm{sppt}=$ soft-plumaged petrel (Pterodroma mollis); aush = Audubon's shearwater (Puffinus lherminieri); kept $=$ Kerguelen petrel (Pterodroma brevirostris); lish = little shearwater (Puffinus assimilis); roal $=$ royal albatross $($ Diomedea epomophora $) ;$ snpt $=$ snow petrel (Pagodroma nivea); bual = Buller's albatross $($ Thalassarche bulleri); papt $=$ Parkinson's petrel $($ Procellaria parkinsoni $) ;$ wlpt $=$ Westland petrel (Procellaria westlandica).

crustaceans are the major prey type for blue petrels (Prince, 1980; Steele and Klages, 1986).

This is the first study to show a significant association between a naturally occurring scented compound and a species of foraging procellariiform seabird. The study is preliminary and does not rule out the possibility that other procellariiforms use DMS or other naturally occurring scented compounds as foraging cues-clearly more work needs to be done. But this result is curious because prions use a foraging behavior unique among procellariiforms; whereas most petrels grasp their prey, prions (or "whale birds") can also filter feed, foraging by skimming over the surface of the water. Morphological adaptations for this foraging strategy include a dorsoventrally compressed bill with comb-like lamellae fringing the side of the palate as well as an elastic buccal pouch for holding prey between the rami of the mandibles. Scattered blue petrels frequently associate with prion flocks (Nevitt, pers. obs.) and may cue off the foraging behavior of prions. These seabirds also have serrations on the sides of the upper mandibles, although these lamellae are not developed to the same degree as in prions. Although little information is available about the visual or olfactory acuity of these seabirds, unpublished work examining prion eye structure suggests that they may not be as well adapted for visual foraging as other procellariiforms that have been studied (G. Martin, University of Birmingham, UK, pers. comm.). Whether other adaptations make prions particularly well suited to using olfactory cues to forage needs to be studied in greater detail.

\section{Questions for the Future}

Years of effort only begin to scratch the surface of any complex biological problem. But this is an exciting time to be studying the sensory aspects of how seabirds forage,

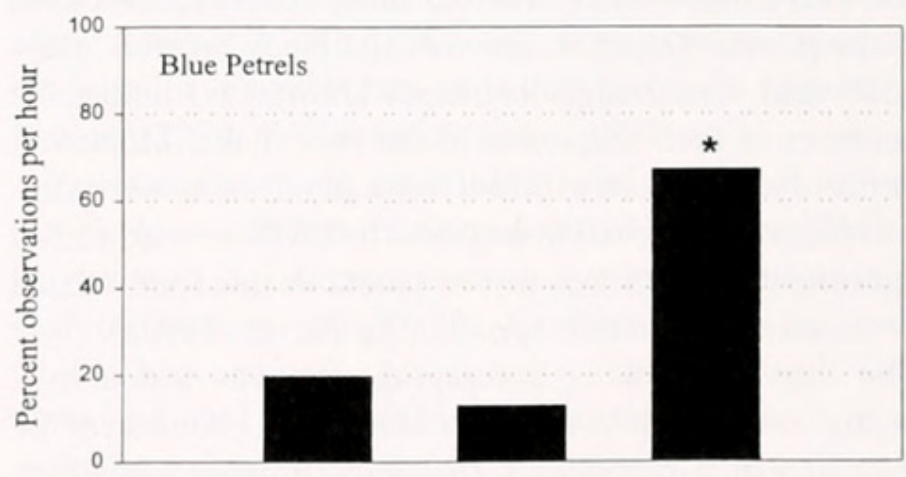

A

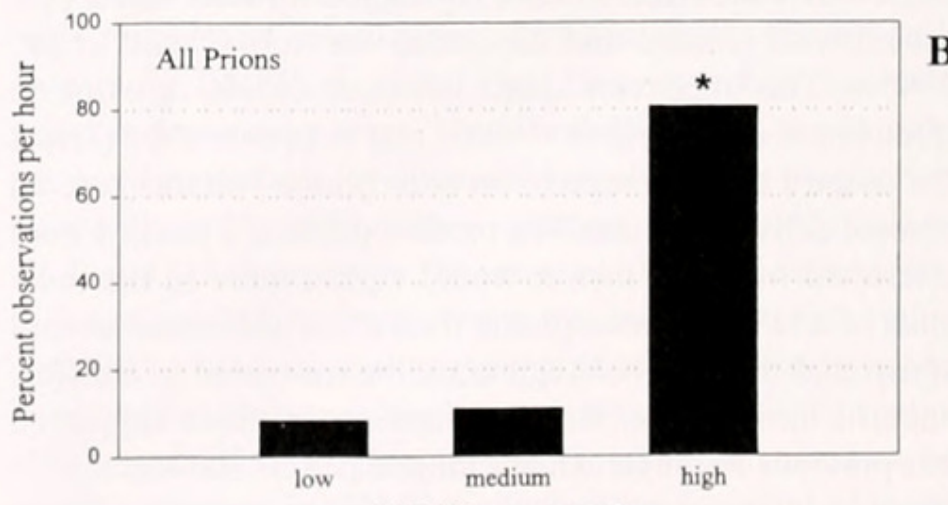

Air DMS concentration

Figure 6. Observations of (A) blue petrels (Halobaena caerulea) and (B) prions (Pachyptila sp.) at low, medium, and high atmospheric concentrations of dimethyl sulfide (DMS). Significant differences $(P<0.05)$ are indicated $(*)$. 
especially since telemetry technology is beginning to allow researchers to address long-standing questions directly from the perspective of a foraging seabird. Since many of these seabirds are large and highly efficient fliers, it is currently possible to instrument them with a variety of devices for monitoring fine-scale behavioral parameters such as turning rate, time spent on the water, and frequency of feeding events (Weimerskirch and Wilson, 1992; Wilson et al., 1995; reviewed by Weimerskirch, 1998). Until recently, most telemetry applications have focused on clarifying basic foraging biology (where do birds go, how frequently do they eat, etc.), rather than on the sensory mechanisms underlying how procellariiforms locate productive feeding areas or prey patches. Potential studies relevant to olfactory foraging include (1) quantifying fine-scale movement patterns while seabirds are en route to foraging areas, (2) identifying whether turning rate changes relative to wind direction once a bird begins an area-restricted search, and (3) identifying how sensory deprivation may influence these and other parameters. As technology improves, it should soon be possible to equip seabirds with sensors that can measure biologically relevant odors in the environment. Such methods will allow researchers to monitor behavioral activity in conjunction with environmental parameters relevant to olfaction.

A second area of study is to examine how different species interact with each other to locate and exploit ephemeral prey resources, and how different sensory adaptations have evolved to shape these interactions. Odors most likely work in conjunction with other cues, particularly visual cues provided by prey as well as by other foraging seabirds or marine mammals. Interspecific behavioral interactions appear to follow consistent trends both at mixed-species feeding aggregations (Harrison et al., 1991) and at experimental olfactory trials performed at sea (Nevitt et al., 1995; Nevitt, 1999a, b). Where procellariiforms forage in mixed-species aggregations, some species dominate these interactions (e.g., giant petrels, which are known to prey upon other petrels) while others (e.g., storm-petrels) tend to avoid them. Different olfactory abilities or adaptations may play a role in defining what foraging strategies different species use in various situations. For example, a heightened sense of smell may give some species a competitive edge in opportunistically locating prey before being displaced by other species (Nevitt, 1999b). This is consistent with our findings that smaller, cryptic species such as prions and storm-petrels responded strongly to DMS-scented slicks whereas larger, more visible species did not. If these storm-petrels, for example, have superior olfactory abilities, they may be able to locate and exploit prey patches before larger species arrive. In addition, since they are cryptic, they may be more difficult for potential competitors to spot. This type of interspecific interaction has also been observed between turkey vultures (Cathartes aura) and black vultures (Coragyps atratus). Where these species co-occur, turkey vul- tures are able to find prey more quickly using a welldeveloped sense of smell. In this case, the smaller black vultures search visually for the larger turkey vultures and then displace them from their find (Buckley, 1997).

Finally, one of the most complex and difficult challenges continues to be identifying and measuring scented compounds associated with natural distributions of prey. Knowing which odors different species can physiologically detect and use as foraging cues will enhance our understanding of species-specific foraging strategies, distribution, and behavior. This information will give us the ability to develop and apply models of olfactory foraging on a broader scale to better understand how odors emitted by prey might extend the range at which a prey patch would be detected by a foraging seabird. Such a framework will be critical in exploring how changes in prey distribution and density might affect the foraging success of procellariiforms.

\section{Acknowledgments}

I thank Tim Bates and Beverly Agler for providing technical assistance in the field. Thanks also to the crew and scientific support staff of the R/V Surveyor. Lisa Holsinger and Victoria Zvonkina assisted with data entry and analysis. I am grateful to Kate Clark for proofreading and for technical assistance in constructing several figures and to Gordon Wolfe for his invaluable contribution to the DMS discussion. The comments of Peter Hodum, Jason Watters, and Kate Clark improved earlier versions of this paper. Finally, I am indebted to Richard Zimmer for his vision in organizing this symposium and for inviting me to submit this manuscript.

\section{Literature Cited}

Ainley, D. G., E. F. O'Connor, and R. J. Boekelheide. 1984. The marine ecology of the birds in the Ross Sea, Antarctica. Ornithol. Monogr. 32: 1-97.

Anderson, D. J., A. J. Schwandt, and H. D. Douglas. 1998. Foraging ranges of Waved Albatrosses in the eastern Tropical Pacific Ocean. Pp. 180-185 in Albatross Biology and Conservation, G. Robertson and R. Gales, eds. Surrey Beatty, Sydney, Australia.

Bang, B. G. 1965. Anatomical adaptations for olfaction in the snow petrel. Nature 205: 513-515.

Bang, B. G. 1966. The olfactory apparatus of tube-nosed birds (Procellariiformes). Acta Anat. 65: 391-415.

Bates, T. S., and P. K. Quinn. 1997. Dimethyl sulfide (DMS) in the equatorial Pacific Ocean (1982 to 1996): evidence of a climate feedback? Geophys. Res. Letters 24: 861-864.

Bell, W., and R. Mitchell. 1972. Chemotactic and growth responses of marine bacteria to algal extracellular products. Biol. Bull. 143: 265277.

Berresheim, H. 1987. Biogenic sulfur emissions from the subantarctic and Antarctic oceans. J. Geophys. Res. 92: 13,245-13,262.

Buckley, N. J. 1997. Experimental tests of the information-center hypothesis with black vultures (Coragyps atratus) and turkey vultures (Cathartes aura). Behav. Ecol. Sociobiol. 41: 267-279.

Cantin, G., M. Levasseur, M. Gosselin, and S. Michaud. 1996. Role of zooplankton in the mesoscale distribution of surface dimethyl sulfide 
concentrations in the Gulf of St. Lawrence, Canada. Mar. Ecol. Prog. Ser. 141: 103-117.

Catard, A., and H. Weimerskirch. 1998. Satellite tracking of petrels and albatrosses: from the tropics to Antarctica. Ostrich 69: 152.

Charnov, E. L. 1976. Optimal foraging, the marginal value theorem. Theor. Popul. Biol. 9: 129-136.

Cherel, Y., and H. Weimerskirch. 1995. Seabirds as indicators of marine resources: black-browed albatrosses feeding on ommastrephid squids in Kerguelen waters. Mar. Ecol. Prog. Ser. 129: 295-300.

Christaki, U., S. Belviso, J. R. Dolan, and M. Corn. 1996. Assessment of the role of copepods and ciliates in the release to solution of particulate DMSP. Mar. Ecol. Prog. Ser. 141: 119-127.

Clark, L., and P. S. Shah. 1992. Information content of odor plumes: what do Leach's storm-petrels know? Pp. 421-427 in Chemical Sig. nals in Vertebrates VI, R. L. Doty and D. Müller-Schwarze, eds. Plenum Press, New York.

Crocker, K. M., M. E. Ondrusek, R. L. Petty, and R. C. Smith. 1995. Dimethyl sulfide, algal pigments and light in an Antarctic Phaeocystis sp. bloom. Mar. Biol. 124: 335-340.

Croxall, J. P., and P. A. Prince. 1994. Dead or alive, night or day: how do albatrosses catch squid? Antarct. Sci. 6: 155-162.

Croxall, J. P., P. A. Prince, I. Hunter, S. J. McInnes, and P. G. Copestake. 1984. The seabirds of the Antarctic Peninsula, islands of the Scotia Sea, and Antarctic continent between $80^{\circ} \mathrm{W}$ and $20^{\circ} \mathrm{W}$ : their status and conservation. Pp. 637-666 in Status and Conservation of the World's Seabirds, J. P. Croxall, P. G. H. Evans, and R. W. Schreiber. eds. ICBP, Cambridge, United Kingdom.

Dacey, J. W. H., and S. G. Wakeham. 1986. Oceanic dimethyl sulfide: production during zooplankton grazing on phytoplankton. Science 233: $1314-1316$.

Daly, K. L., and G. R. DiTullio. 1996. Particulate dimethylsulfoniopropionate removal and dimethyl sulfide production by zooplankton in the Southern Ocean. Pp. 223-238 in Biological and Environmental Chemistry of DMSP and Related Sulfonium Compounds. R. P. Kiene, P. T Visscher, M. D. Kellor, and G. O. Kirst, eds. Plenum Press, New York.

de Souza, M. P., Y. P. Chen, and D. C. Yoch. 1996. Dimethylsulfoniopropionate lyase from the macroalga Ulva curvata: purification and characterization of the enzyme. Planta 199: 433-438.

Dusenbery, D. B. 1992. Sensory Ecology. W. H. Freeman, New York. $558 \mathrm{pp}$.

Gage, D. A., D. Rhodes, K. D. Nolte, W. A. Hicks, T. Leustek, A. J. L. Cooper, and A. D. Hanson. 1997. A new route for synthesis of dimethylsulphoniopropionate in marine algae. Nature 387: 891-894.

Gibson, J. A. E., R. C. Garrick, H. R. Burton, and A. R. McTaggart. 1990a. Dimethyl sulfide and the alga Phaeocystis pouchetii in Antarctic coastal waters. Mar. Biol. 104: 339-346.

Gibson, J. A. E., R. C. Garrick, H. R. Burton, and A. R. MeTaggart. 1990b. Dimethyl sulfide levels in the ocean close to the Antarctic continent. Geomicrobiol. J. 6: 179-184.

Gibson, J. A. E., K. M. Swadling, and H. R. Burton. 1996. Acrylate and dimethyl sulfoniopropionate (DMSP) concentrations during an Antarctic phytoplankton bloom. Pp. 213-222 in Biological and Environmental Chemistry of DMSP and Related Sulfonium Compounds, R. P. Kiene, P. Visscher, G. Kirstand, and M. Keller, eds. Plenum Press, New York.

Grubb, T. C., Jr. 1972. Smell and foraging in shearwaters and petrels Nature 327: 404-405.

Harrison, N. M., M. J. Whitehouse, D. Heinemann, P. A. Prince, G. L. Hunt Jr., and R. R. Veit. 1991. Observations of multi-species feeding flocks around South Georgia. Auk 108: 801-810.

Hasler, A. D., and A. T. Scholz. 1983. Olfactory Imprinting and Homing in Salmon. Springer-Verlag, New York. 134 pp.

Hauser, D. C. R., M. Levandowsky, S. H. Hunter, L. Chunosoff, and J. S. Hollwitz. 1975. Chemosensory responses by the heterotrophic marine dinoflagellate Crypthecodinium cohnii. Microb. Ecol. 1: 246254.

Hutchison, L. V., and B. M. Wenzel. 1980. Olfactory guidance in foraging by procellariiforms. Condor 82: 314-319

Imber, M. J. 1981. Diets of storm petrels Pelagodroma and Garrodia and of prions Pachyptila (Procellariiformes). Pp. 63-88 in Proceedings of the Symposium on Birds of the Sea and Shore, J. Cooper, ed. African Seabird Group, Cape Town, South Africa

Jouventin, P., and H. Weimerskirch. 1990. Satellite tracking of wandering albatrosses. Nature 343: 746-748.

Kellor, M. D., W. K. Bellows, and R. R. Guillard. 1989. Dimethyl sulphide production in marine phytoplankton. Pp. 167-182 in Biogenic Sulfur in the Environment. E. S. Saltzman and W. J. Cooper, eds. American Chemical Society, Washington, DC.

Kocsis, M. G., K. D. Nolte, D. Rhodes, T.-L. Shen, D. A. Gage, and A. D. Hanson. 1998. Dimethylsulfoniopropionate biosynthesis in Spartina alterniflora. Plant Physiol. 117: 273-281

Kwint, R. L. J., and K. M. Kramer. 1996. A new sensitive tracer for the determination of zooplankton grazing activity. J. Plankton Res. 18: 1513-1518.

Leck, C., U. Larsson, L. E. Bœgander, S. Johansson, and S. Hajdu. 1989. DMS in the Baltic Sea-annual variability in relation to biological activity. J. Geophys. Res. 95: 3353-3363

Lequette, B., C. Verheyden, and P. Jouventin. 1989. Olfaction in sub-Antarctic seabirds: its phylogenetic and ecological significance. Condor 91: 732-735.

Levasseur, M., S. Michaud, J. Egge, G. Cantin, J. C. Nejstgaard, R. Sanders, E. Fernandez, P. T. Solberg, B. Heimdal, and M. Gosselin. 1996. Production of DMSP and DMS during a mesocosm study of an Emiliania huxleyi bloom: influence of bacteria and Calanus finmarchicus grazing. Mar. Biol. 126: 609-618.

Liddle, G. M. 1994. Interannual variation in the breeding biology of the Antarctic prion Pachyptila desolata at Bird Island, South Georgia. J. Zool. Lond. 234: 125-139.

Lohmann, K. J. 1992. How sea turtles navigate. Sci. Am. 266: 82-88.

Matrai, P. A., and M. D. Keller. 1993. Dimethyl sulfide in a large-scale coccolithophore bloom in the Gulf of Maine. Continental Shelf Res. 13: 831-843.

McTaggart, A. R., and H. Burton. 1992. Dimethyl sulfide concentrations in the surface waters of the Australasian Antarctic and Subantarctic oceans during an austral summer. J. Geophys. Res. 97: 14,40714,412 .

Nevitt, G. 1999a. Foraging by seabirds on an olfactory landscape. Am. Sci. 87: 46-53.

Nevitt, G. 1999b. Olfactory foraging in Antarctic seabirds: a speciesspecific attraction to krill odors. Mar. Ecol. Prog. Ser. 177: 235-241.

Nevitt, G., and A. Dittman. 1998. A new model for olfactory imprinting in salmon. Integr. Biol. 1: 215-223.

Nevitt, G. A., and R. R. Veit. 1999. Mechanisms of prey patch detection by foraging seabirds. Pp. 2072-2082 in Proceedings of the 22nd International Ornithological Congress, N. J. Adams and R. H. Slotow, eds. BirdLife South Africa, Johannesburg

Nevitt, G. A., R. R. Veit, and P. M. Kareiva. 1995. Dimethyl sulphide as a foraging cue for Antarctic Procellariiform seabirds. Nature 376: $680-682$

Nguyen, B. C., S. Belviso, N. Mihalopoulos, J. Gostan, and P. Nival. 1988. Dimethyl sulfide production during natural phytoplankton blooms. Mar. Chem. 24: 133-141.

Nishiguchi, M. K., and L. J. Goff. 1995. Isolation, purification, and characterization of DMSP lyase (dimethylpropiothetindethiomethylase (4.4.1.3)) from the red alga Polysiphonia paniculata. J. Phycol, 31: $564-574$

Papi, F., L. Fiore, V. Fiachi, and S. Benvenuti. 1972. Olfaction and homing pigeons. Monitore Zool. Ital. 6: 85-95

Pennycuick, C. J. 1982. The flight of petrels and albatrosses (Procel- 
lariiformes), observed in South Georgia and its vicinity. Philos. Trans. R. Soc. Lond. B300: 75-106.

Pennycuick, C. J. 1987. Flight of seabirds. Pp. 43-62 in Seabirds: Feeding Biology and Role in Marine Ecosystems, J. P. Croxall, ed. Cambridge University Press, Cambridge

Prince, P. A. 1980. The food and feeding ecology of blue petrel (Halobaena caerulea) and dove prion (Pachyptila desolata). J. Zool. Lond. 190: 59-76.

Prince, P. A., and P. G. Copestake. 1990. Diet and aspects of Fairy Prions breeding at South Georgia. Notornis 37: 59-69.

Prince, P. A., and R. A. Morgan. 1987. Diet and feeding ecology of Procellariiformes. Pp. 135-171 in Seabirds: Feeding Ecology and Role in Marine Ecosystems, J. P. Croxall, ed. Cambridge University Press, Cambridge.

Prince, P. A., J. P. Croxall, P. N. Trathan, and A. G. Wood. 1998. The pelagic distribution of South Georgia albatrosses and their relationships with fisheries. Pp. 137-167 in Albatross Biology and Conservation, G Robertson and R. Gales, eds. Surrey Beatty, Sydney, Australia.

Reid, K., J. P. Croxall, and T. M. Edwards. 1997. Interannual variation in the diet of the Antarctic Prion Pachyptila desolata at South Georgia Emu 97: 126-132.

Ridoux, V. 1994. The diets and dietary segregation of seabirds at the subantarctic Crozet Islands. Mar. Ornithol, 22: 1-192.

Rodhouse, P. G., M. R. Clarke, and A. W. A. Murray. 1987. Cephalopod prey of the Wandering Albatross Diomedea exulans. Mar. Biol 91: $1-10$.

Sagar, P. M., and H. Weimerskirch. 1996. Satellite tracking of Southern Buller's Albatrosses from the Snares, New Zealand. Condor 98: $649-652$.

Sieburth, J. M. 1959. Antibacterial activity of Antarctic marine phytoplankton. Limnol. Oceanogr. 4: 419-424.

Sieburth, J. M. 1960. Acrylic acid, an "antibiotic" principle in Phaeo cystis blooms in Antarctic waters. Science 132: 676-677.

Sieburth, J. M. 1961. Gastrointestinal microflora of Antarctic birds. J. Bacteriol. 77: 521-531.

Steele, W. K., and N. T. Klages. 1986. Diet of the blue petrel at sub-Antarctic Marion Island. S. Afr. J. Zool. 21: 252-256

Stefels, J., and L. Dijkhuizen. 1996. Characteristics of DMSP-lyase in Phaeocystis sp. (Prymnesiophyceae). Mar. Ecol. Prog. Ser. 131: 307313.

Steinke, M., C. Daniel, and G. O. Kirst. 1996. DMSP lyase in marine macro- and microalgae: intraspecific differences in cleavage activity. Pp. 317-324 in Biological and Environmental Chemistry of DMSP and Related Sulfonium Compounds, R. P. Kiene, P. Visscher, G. Kirst, and M. Keller, eds. Plenum Press, New York.

Steinke, M., G. V. Wolfe, and G. O. Kirst. 1998. Partial characterization of dimethyl sulfoniopropionate (DMSP) lyase in 6 strains of Emiliania huxleyi. Mar. Ecol. Prog. Ser. 175: 215-225.

Stephens, D. W., and Krebs, J. R. 1986. Foraging Theory. Princeton University Press, Princeton. 247 pp.

Tasker, M. L., P. H. Jones, T. Dixon, and B. F. Blake. 1984. Counting seabirds at sea from ships: a review of the methods employed and suggestions for a standardized approach. Auk 101: 567-577.

Tokunaga, T., H. Iida, and K. Nakamura. 1977. Formation of dimethyl sulfide in Antarctic krill, Euphausia superba. Bull. Jpn. Soc. Sci. Fish. 43: 1209-1217.

Trossat, C., K. D. Nolte, and A. D. Hanson. 1996. Evidence that the pathway of dimethylsulfoniopropionate biosynthesis begins in the cytosol and ends in the chloroplast. Plant Physiol. 111: 965-973
Turner, S. M., P. D. Nightingale, W. Broadgate, and P. S. Liss. 1995. The distribution of dimethyl sulphide and dimethylsulphoniopropionate in Antarctic waters and sea ice. Deep Sea Res. 42: 1059-1080.

Veit, R. R., and P. A. Prince. 1997. Individual and population level dispersal of Black-browed and Grey-headed Albatrosses in response to Antarctic krill. Ardea 85: 129-134

Waldvogel, J. A. 1987. Olfactory navigation in homing pigeons: are the current models atmospherically realistic? Auk 104: 369-379

Wallraff, H. G. 1981. The olfactory component of pigeon navigation steps of analysis. J. Comp. Physiol. 143: 411-422.

Warham, J. 1990. The Petrels: Their Ecology and Breeding Systems. Academic Press, New York. $440 \mathrm{pp}$

Weimerskirch, H. 1998. Foraging strategies of southern albatrosses and their relationship with fisheries. Pp. 168-179 in Albatross Biology and Conservation, G. Robertson and R. Gales, eds. Surrey Beatty, Sydney, Australia.

Weimerskirch, H., and G. Robertson. 1994. Satellite tracking of lightmantled sooty albatrosses. Polar Biol. 14: 123-126.

Weimerskirch, H., and R. P. Wilson. 1992. When do wandering albatrosses Diomedea exulans forage? Mar. Ecol. Prog. Ser. 86: 297-300.

Weimerskirch, H., P. Jouventin, and J. C. Stahl. 1986. Comparative ecology of the six albatross species breeding on the Crozet Islands. Ibis 128: 195-213.

Weimerskirch, H., M. Salamolard, F. Sarrazin, and P. Jouventin. 1993. Foraging strategy of Wandering Albatrosses through the breeding season: a study using satellite telemetry. Auk 110: 325-342.

Weimerskirch, H., C. P. Doncaster, and F. Cuénot-Chaillet. 1994. Pelagic seabirds and the marine environment: foraging patterns of wandering albatrosses in relation to prey availability and distribution. Proc. R. Soc. Lond. Ser. B 255: 91-97.

Wilson, R. P., H. Weimerskirch, and P. Lys. 1995. A device for measuring seabird activity at sea. J. Avian Biol. 26: 172-176.

Wolfe, G. V., and M. Steinke. 1996. Grazing-activated production of dimethyl sulfide (DMS) by two clones of Emiliania huxleyi. Limnol. Oceanogr. 41: 1151-1160.

Wolfe, G. V., E. B. Sherr, and B. S. Sherr. 1994. Release and consumption of DMSP from Emiliania huxleyi during grazing by Oxyrrhis marina. Mar. Ecol. Prog. Ser. 111: 111-119.

Wolfe, G. V., M. Levasseur, G. Cantin, and S. Michaud. In press. Microbial production and consumption of dimethyl sulfide (DMS) in the Labrador Sea. Aquat. Microb. Ecol.

Yang, H., A. R. McTaggart, A. T. Davidson, and H. Burton. 1992. Natural productivity of acrylic acid and dimethyl sulphide during a summer bloom of Phaeocystis pouchetii in Antarctic coastal water. Antarct. Res. 3: 26-43.

Yang, H., A. R. McTaggart, A. T. Davidson, and H. Burton. 1994. Measurement of acrylic acid and dimethyl sulfide in Antarctic coastal water during a summer bloom of Phaeocystis pouchetii. Proc. MIPR Symp. Polar Biol. 7: 43-52.

Yvon, S. A., E. S. Saltzman, D. J. Cooper, T. S. Bates, and A. M. Thompson. 1996. Atmospheric sulfur cycling in the tropical Pacific marine boundary layer $\left(12^{\circ} \mathrm{S}, 135^{\circ} \mathrm{W}\right)$ : a comparison of field data and model results. 1. Dimethylsulfide. J. Geophys. Res. 101: 6899-6909.

Zimmer-Faust, R. K., M. P. de Souza, and D. C. Yoch. 1996. Bacterial chemotaxis and its potential role in marine dimethylsulfide production and biogeochemical sulfur cycling. Limnol. Oceanogr. 41: $1330-1334$. 


\section{$2 \mathrm{BHL}$ Biodiversity Heritage Library}

Nevitt, G A. 2000. "Olfactory foraging by Antarctic procellariiform seabirds: life at high Reynolds numbers." The Biological bulletin 198, 245-253. https://doi.org/10.2307/1542527.

View This Item Online: https://www.biodiversitylibrary.org/item/17199

DOI: https://doi.org/10.2307/1542527

Permalink: https://www.biodiversitylibrary.org/partpdf/2456

\section{Holding Institution}

MBLWHOI Library

\section{Sponsored by}

MBLWHOI Library

\section{Copyright \& Reuse}

Copyright Status: In copyright. Digitized with the permission of the rights holder.

License: http://creativecommons.org/licenses/by-nc-sa/3.0/

Rights: https://biodiversitylibrary.org/permissions

This document was created from content at the Biodiversity Heritage Library, the world's largest open access digital library for biodiversity literature and archives. Visit BHL at https://www.biodiversitylibrary.org. 